\title{
Evaporative cooling system for gestating and lactating sows: a systematic review
}

\section{Melissa Fabíola dos Santos Alves Mendes ${ }^{1^{*}}$ (1) David Henrique de Oliveira ${ }^{1}$ (i) Fábio Loures Cruz $^{2}$ (i) Múcio André dos Santos Alves Mendes $^{3}{ }^{(-)}$Bruna Pontara Vilas Boas Ribeiro ${ }^{4}[$ Rony Antônio Ferreira ${ }^{1}$ (1)}

\begin{abstract}
${ }^{1}$ Departamento de Zootecnia, Universidade Federal de Lavras (UFLA), 37200-900, Lavras, MG, Brasil. E-mail: melissamendes@zootecnista.com. br. "Corresponding author.

${ }^{2}$ Departamento de Medicina Veterinária, Universidade Federal de Lavras (UFLA), Lavras, MG, Brasil.

${ }^{3}$ Instituto de Ciências Agrárias e Ambientais, Universidade Federal do Mato Grosso (UFMT), Sinop, MT, Brasil.

${ }^{4}$ Departamento de Engenharia Agrícola, Universidade Federal de Lavras (UFLA), Lavras, MG, Brasil.

ABSTRACT: Climatic characteristics of the production sites of pigs influence the yield of the system, with breeding sows being a category extremely sensitive to high temperatures, especially when their upper critical temperature is reached. This review evaluated the effects of the evaporative cooling system on environmental, physiological and performance parameters in breeding sows. By means of this review, a bibliographic search was performed using the following keywords: sow; swine; gilt and pig combined individually with the expression 'evaporative cooling'. A total of 11 papers met the prerequisites determined to compose the systematic review and the studies involved gestating and lactating sows maintained in environments that presented ambient temperatures between 21.5 and $34.8{ }^{\circ} \mathrm{C}$ and relative humidity between 32.2 and $84.2 \%$. The evaporative cooling system was used in order to cool the macro or micro environment. It can be concluded that the use of evaporative cooling system promotes increase in feed intake per lactating sow, decrease in weight loss in lactation, increase of weight of piglets at weaning, temperature reduction of the barns and decrease of the respiratory rate of the sows. For gestating sows, no changes in reproductive performance were reported.
\end{abstract}

Key words: environment, heat, reproduction, sows, swine production.

Sistema de resfriamento evaporativo para porcas gestantes e lactantes: uma revisão sistemática

RESUMO: As características climáticas dos locais de produção de suínos influenciam na produtividade do sistema, sendo as fêmeas em reprodução uma categoria extremamente sensivel a elevadas temperaturas, principalmente, quando é atingida sua temperatura critica superior. Por meio desta revisão, avaliou-se os efeitos do sistema de resfriamento evaporativo sobre parâmetros ambientais, fisiológicos e de desempenho em fêmeas suínas em reprodução. Uma pesquisa bibliográfica foi realizada utilizando as palavras-chave: sow; swine; gilt e pig combinadas individualmente com a expressão 'evaporative cooling'. Um total de 11 artigos atendeu aos pré-requisitos determinados para compor a revisão sistemática, sendo que os estudos envolveram fêmeas gestantes e lactantes mantidas em ambientes que apresentaram temperaturas entre 21,5 e $34,8^{\circ} \mathrm{C}$, e umidade relativa entre 32,2 e $84,2 \%$. O sistema de resfriamento evaporativo foi usado de forma a resfriar o macro ou micro ambiente. Pode-se concluir que o uso do sistema de resfriamento evaporativo promove aumento do consumo de ração para porcas em lactação, diminuição da perda de peso na lactação, aumento do peso dos leitões ao desmame, redução da temperatura dos galpões e diminuição da frequência respiratória das porcas. Para porcas gestantes, não foram encontradas alterações no desempenho reprodutivo. Palavras-chave: ambiente, calor, reprodução, porcas, produção de suínos.

\section{INTRODUCTION}

Heat stress is one of the major economic concerns in pig production and represents a future challenge for the farmers (HILBRANDS et al., 2017;
CROSS et al., 2018). Increase in environmental temperature resulting from climate change over the last few years and the increased production of pigs in tropical regions cause that new technologies to be incorporated into the production system to 
ensure greater animal comfort and yield (LONTOC et al., 2016; ROSS et al., 2017). Pigs present few sudoriparous glands and are non-functional and in addition, they possess a thick layer of subcutaneous fat that makes them inefficient in the dissipation of the heat coming from the metabolism which can compromise their performance (ROSS et al., 2015; SEELENBINDER et al., 2018).

Present sows are highly susceptible to heat due to the greater production potential resulting from the intense genetic selection conducted. Modern sows have become more metabolically demanding, especially when gestating or lactating, which increased the metabolic heat production compared to the older strains (CABEZÓN et al., 2017).

Feed consumption is one of the main parameters of performance affected, being reduced in heat stress conditions, which can cause increased mobilization of body tissues and greater weight loss in lactation, compromising the posterior reproductive performance (BAUMGARD \& RHOADS, 2013). High temperatures can also cause physiological changes that reflect on elevation of surface temperature (ST) and rectal temperature (RT), and increase in respiratory rate (RR), as an attempt to dissipate surplus heat and reduce negative effects on maintenance and yield (MALMKVIST et al., 2012). Although, there have been advances in barn cooling systems, the efficiency of pig production continues to be negatively affected during the warmer months (CROSS et al., 2018). This can be presented in two main ways, such as evaporative plates installed on the sides of the barns so that the external air passes through them and enters the already cooled barn or so that the air cooled by the plates is directed, through tubes, directly to the sow's cervical region, the latter being the way normally used for lactating sows.

This systematic review aimed to check the effects of the use of the evaporative cooling system on the environmental, physiological and performance parameters of gestating or lactating sows.

\section{MATERIALS AND METHODS}

\section{Search strategy}

An electronic search was conducted in the month of May 2019, in the following databases: Periodicals Capes (site), Scopus (site), Scielo, Web of Science (site). The keywords used were: evaporative cooling; sow; swine; gilt; and pig. From these combinations in pairs were created, always keeping the word 'evaporative cooling'. The search was carried out by five researchers, separately, in order to obtain greater comprehensiveness. Books, chapter books, abstracts, scientific notes and papers done with other species were not selected.

\section{Selection and exclusion of papers}

The studies that evaluated the effect of evaporative cooling on the environmental variables of the barn and/or on the reproductive performance of sows and/or on the physiological parameters were selected. There was no date or language restriction for the selected papers. Articles in which other categories of the pig production system were evaluated were excluded. Papers found by more than one researcher were considered duplicates and excluded. In case of disagreement between the researchers in the selection of some article, the criteria were reviewed and discussed by all. The number of articles reported from the predefined combinations is in table 1 .

\section{Scoring criteria}

The criteria were defined based on other papers already published (FERREIRA et al., 2013) and from the previous experience of the authors. For each criterion, the papers were scored in 1 or 2, where 1 represents inadequate or not described, and 2 is suitable or described.

A - Randomization: randomized trials received score 2; non-randomized studies or when they were not clearly defined in the text, received a score of 1 .

B - Control group: studies that used control group received score 2; when they did not have a control group or were not mentioned in the text, received a score of 1.

C-Sample size: papers with more than 30 replications received a score of 2 ; article with up to 30 repetitions received a score of 1 .

D - Variables evaluated: studies that evaluated sow performance, environmental variables and physiological parameters were scored 2 ; while studies that evaluated two or fewer parameters received a score of 1 .

E - Sow weight: paper that accompanied the sow's body condition received a score of 2 , while papers that did not accompany were given a score of 1 .

F - Characterization of the barn: articles that characterized the barn structure received a score of 2 ; while papers that did not describe received a score of 1 .

G - Temperature measurement: papers in which the temperature and/or external UR were measured received a score of 2; while papers that measured only inside the barn received a score of 1 . 
Table 1 - Detailed results of the search in each database according to the key words.

\begin{tabular}{|c|c|c|c|c|c|c|c|}
\hline \multirow[t]{2}{*}{ Base } & \multirow[t]{2}{*}{ Search } & \multicolumn{5}{|c|}{ Combinations ${ }^{*}$} & \multirow[t]{2}{*}{ Total $^{\dagger}$} \\
\hline & & 1 & 2 & 3 & 4 & 5 & \\
\hline \multirow{3}{*}{ Scielo } & Total number & 3 & 5 & 0 & 3 & 0 & 11 \\
\hline & Number of selected papers & 3 & 0 & 0 & 2 & 0 & 5 \\
\hline & Number of repeated papers & 0 & 2 & 0 & 0 & 0 & 2 \\
\hline \multirow{3}{*}{ Capes Periodics } & Total Number & 261 & 337 & 77 & 176 & 1117 & 1968 \\
\hline & Number of selected papers & 8 & 2 & 0 & 0 & 4 & 14 \\
\hline & Number of repeated papers & 0 & 2 & 0 & 0 & 4 & 6 \\
\hline \multirow{3}{*}{ ISI Web of Science } & Total number & 16 & 21 & 3 & 8 & 32 & 80 \\
\hline & Number of selected papers & 9 & 0 & 0 & 0 & 0 & 9 \\
\hline & Number of repeated papers & 0 & 0 & 0 & 0 & 0 & 0 \\
\hline \multirow{3}{*}{ Scopus } & Total number & 17 & 34 & 3 & 12 & 41 & 107 \\
\hline & Number of selected papers & 8 & 3 & 0 & 5 & 5 & 21 \\
\hline & Number of repeated papers & 0 & 2 & 0 & 5 & 5 & 12 \\
\hline Number of papers selected for the search ${ }^{\ddagger}$ & & & & & & & 11 \\
\hline
\end{tabular}

*1 - Evaporative cooling and sow; 2 - Evaporative cooling and swine; 3 - Evaporative cooling and gilt; 4 - Evaporative cooling and piglet; 5 - Evaporative cooling and pig. 'Total number of papers found may be higher than the number of papers used due to the fact that in the same database appear the same papers with different key words. ${ }^{\star}$ Final number of papers selected.

\section{RESULTS}

According to the pre-established selection/ exclusion criteria, 50 papers were pre-selected and subsequently evaluated by the authors. A total of 11 papers were selected for the systematic review (Table 1). The evaluation of the selected articles as described in the material and methods (Table 2).

The papers published on the use of the evaporative cooling system for sows were concentrated between the years 2008 and 2018, with only one study published in 1998. Table 3 presents the general information of the papers (Table 3 ).

Internal temperature of the barn was evaluated in $73 \%$ of the articles. The use of the negative pressure evaporative cooling system reduced the room temperature by approximately $2.0{ }^{\circ} \mathrm{C}$. The most significant reduction was $2.9{ }^{\circ} \mathrm{C}$ (BOTTO et al., 2014).

The relative humidity was evaluated in $73 \%$ of the papers, so that in most of the studies, the negative pressure evaporative cooling system increased relative humidity, varying from $0.9 \%$ (MORALES et al., 2013) to 19\% (BOTTO et al., 2014). Air velocity was described in $27 \%$ of the studies; JUSTINO et al. (2014) reported an increase of $3.15 \mathrm{~m} \mathrm{~s}^{-1}$ (Table 4).

In $36 \%$ of the studies, the bioclimatic index temperature and humidity index was determined and in one study the black globe temperature and humidity index was calculated. The use of the duct fan evaporative cooling system allowed the temperature and humidity index to be reduced by up to 3.1 scores (JUSTINO et al., 2015). In 73\% of the studies, environmental variables were used for evaluation of the barns; however in three studies the reported values were not specified (Table 4).

Regarding the physiological parameters, a decrease of $0.3{ }^{\circ} \mathrm{C}$ in the rectal temperature of lactating sows was observed with the use of the evaporative cooling system. Surface temperature was evaluated in three studies in lactating sows and in two of them a maximum reduction of $0.5^{\circ} \mathrm{C}$ in the temperature of the ones submitted to the cooling system was reported. In three of the four studies evaluating the respiratory rate of sows, a reduction was observed, varying from four to 23 movements per minute (Table 5).

In $64 \%$ of the studies, the effect of the evaporative cooling system on lactating sows was evaluated; in $27 \%$, they were evaluated in both categories and in one study, gestating sows. Regarding the characterization of the cooling system, the cooled air was directed onto the cervical region of the sows in six of the 11 studies, in the others, the whole barn was cooled. Of the studies evaluated, $55 \%$ used performance variables and/or reproductive performance to evaluate the sows submitted to 
Table 2 - Evaluation of the quality of the papers according to the selection criteria.

\begin{tabular}{|c|c|c|c|c|c|c|c|c|}
\hline Author/Year & A & B & $\mathrm{C}$ & $\mathrm{D}$ & $\mathrm{E}$ & $\mathrm{F}$ & G & Total \\
\hline Turco et al. (1998) & 2 & 2 & 1 & 1 & 1 & 2 & 2 & 11 \\
\hline Romanini et al. (2008) & 2 & 2 & 2 & 1 & 2 & 2 & 1 & 12 \\
\hline Kiefer et al. (2012) & 2 & 2 & 2 & 1 & 1 & 1 & 1 & 10 \\
\hline Morales et al. (2013) & 2 & 1 & 2 & 1 & 2 & 2 & 1 & 11 \\
\hline Justino et al. (2014) & 2 & 2 & 2 & 1 & 1 & 2 & 1 & 11 \\
\hline Wang et al. (2014) & 1 & 1 & 2 & 1 & 1 & 2 & 1 & 9 \\
\hline Justino et al. (2015) & 1 & 2 & 1 & 2 & 2 & 1 & 1 & 10 \\
\hline Lontoc et al. (2016) & 1 & 2 & 2 & 1 & 2 & 1 & 1 & 10 \\
\hline Botto et al. (2014) & 1 & 2 & 2 & 1 & 1 & 1 & 1 & 9 \\
\hline Perin et al. (2016) & 1 & 2 & 2 & 1 & 2 & 1 & 1 & 10 \\
\hline Chen et al. (2018) & 1 & 2 & 1 & 1 & 1 & 1 & 1 & 8 \\
\hline
\end{tabular}

A - randomization: 2 for randomized and 1 for non-randomized or unclear in the text; B - control group: 2 for trials using a control group and 1 for those without a control group or when unclear in the text; $\mathrm{C}$ - sample size: 2 for trials using more than 30 sows per treatment and 1 for those using 30 or fewer sows or when unclear in the text; D - variables evaluated: 2 for studies that evaluated sow performance, environmental variables and physiological parameters and 1 for studies that evaluated two or fewer parameters; E - sow weight: 2 for paper that accompanied the sow's body condition and 1 for papers that did not accompany or unclear in the text; $\mathrm{F}$ characterization of the barn: 1 for papers that characterized the barn structure and 2 for papers that did not describe or when unclear in the text; $\mathrm{G}$ - temperature measurement: 1 for papers in which the temperature and / or external UR were measured and 2 for papers that measured only inside the barn.

the evaporative cooling system, and $45 \%$ used physiological variables.

From the studies carried out with lactating sows, only one did not evaluate the feed consumption by sows. All others reported an increase in this variable $\left(\mathrm{kg} \mathrm{d}^{-1}\right)$ with the use of the evaporative cooling system. This increase varied from $0.40 \mathrm{~kg} \mathrm{~d}^{-1}$ (MORALES et al., 2013) to $1,67 \mathrm{~kg} \mathrm{~d}^{-1}$ (KIEFER et al., 2012), the latter observed in primiparous sows (Table 6).

The body condition of lactating sows was evaluated in $55 \%$ of the studies and in $66 \%$ of them, improvement was observed. The condition was evaluated by means of backfat thickness and/or weight loss percentage during lactation. ROMANINI et al. (2008) reported higher backfat thickness in sows submitted to treatment with evaporative cooling. With regard to weight loss, KIEFER et al. (2012) observed lower weight loss in sows submitted to cooling $(<8 \%)$ (Table 6$)$.

The milk yield was evaluated in only one study, so that the evaporative cooling system allowed the average increase of $19 \%$ in sows of parity one and two and $13 \%$ in parity three to eight, respectively (KIEFER et al., 2012) when compared to the control group. The weaning-to-estrus interval was evaluated in four studies. With the cooling system, a mean decrease of 3.8 days (10.9 to 7.1 days) in the weaningto-estrus interval of primiparous sows (PERIN et al., 2016) was observed (Table 6).
In $54 \%$ of the studies, the effect of the evaporative cooling system on pregnancy and / or lactation on some piglet-related variable was evaluated. From these parameters, piglet weight at weaning was the most influenced and showed improvement of up to $22 \%$ for lactating sows (parity one and two) when submitted to the cooling system (KIEFER et al., 2012). Differences in mortality of piglets with the use of cooling were not observed (Table 6).

The number of total born piglets, number of piglets born alive and weight of the piglets at birth were evaluated by the minority of the studies. In the studies with gestating sows only one (LONTOC et al., 2016) evaluated these parameters and no differences among the other treatments were reported.

According to the results of the studies, the use of evaporative cooling promotes increase in feed intake of on average of $1.0 \mathrm{~kg} \mathrm{~d}^{-1}$ (4.0 to $5.0 \mathrm{~kg} \mathrm{~d}^{-1}$ ) per lactating sow, $6 \%$ (7 to $1 \%$ ) decrease in weight loss in lactation, average increase of $9 \%$ (5.8 to $6.4 \mathrm{~kg}$ ) of weight of piglets at weaning, reduction of the temperature of the barns by $2{ }^{\circ} \mathrm{C}\left(27\right.$ to $\left.25^{\circ} \mathrm{C}\right)$ and decrease of the respiratory rate of the sows at 14 movements per minute (61 to 47 movements per minute).

\section{DISCUSSION}

Systematic reviews are tools that allow the generation of more reliable and useful data from 
Table 3 - Summary of the general data of the studies selected to evaluate the evaporative cooling system.

\begin{tabular}{|c|c|c|c|c|c|c|}
\hline Author/year & $\begin{array}{l}\text { Animal } \\
\text { category }\end{array}$ & $\begin{array}{c}\text { Number of } \\
\text { animals per } \\
\text { treatment / } \\
\text { genetics }\end{array}$ & Parity & Study site & $\begin{array}{l}\text { Season of the } \\
\text { year/period }\end{array}$ & Parameters evaluated \\
\hline $\begin{array}{l}\text { Turco et al. } \\
\text { (1998) }\end{array}$ & $\begin{array}{l}\text { Lactating } \\
\text { sows }\end{array}$ & $\begin{array}{l}\text { 26/Landrace } \\
\text { and Large } \\
\text { White }\end{array}$ & NSP & $\begin{array}{l}\text { Faxinal do Guedes - } \\
\text { Santa Catarina, Brazil }\end{array}$ & Summer/NSP & BGHI, RTL e RH \\
\hline $\begin{array}{l}\text { Romanini et } \\
\text { al. (2008) }\end{array}$ & $\begin{array}{l}\text { Gestating } \\
\text { and } \\
\text { lactating } \\
\text { sows }\end{array}$ & $63^{\mathrm{a}} / 42^{\mathrm{b}} \mathrm{NSP}$ & 1 & $\begin{array}{l}\text { Campinas, São Paulo, } \\
\text { Brazil }\left(47^{\circ} 05^{\prime} \mathrm{W}, 22^{\circ} 54^{\prime}\right. \\
\text { S, altitude of } 640 \mathrm{~m})\end{array}$ & $\begin{array}{l}\text { Summer and } \\
\text { Winter/NSP }\end{array}$ & $\begin{array}{l}\text { PBW, BWW (21 days); } \\
\text { Sow: ST; BFT; RR }\end{array}$ \\
\hline $\begin{array}{l}\text { Kiefer et al. } \\
(2012)\end{array}$ & $\begin{array}{l}\text { Lactating } \\
\text { sows }\end{array}$ & $\begin{array}{l}\text { Min } \\
\text { 22/commercia } \\
1 \text { hybrids }\end{array}$ & 3 to 8 & $\begin{array}{c}\text { Campo Grande, MS, in } \\
\text { the Central West region } \\
\text { of Brazil }\end{array}$ & $\begin{array}{l}\text { Summer/Janua } \\
\text { ry and } \\
\text { February }\end{array}$ & $\begin{array}{l}\text { Sow: FI, body weight } \\
\text { variation, milk production } \\
\text { and LD; Piglets: GPD }\end{array}$ \\
\hline $\begin{array}{l}\text { Morales et al. } \\
(2013)\end{array}$ & $\begin{array}{l}\text { Lactating } \\
\text { sows }\end{array}$ & $\begin{array}{l}\text { Min 79/ } \\
\text { Landrace x } \\
\text { Large White, } \\
\text { Agroceres } \\
\text { PIC }^{\circledR}\end{array}$ & $\begin{array}{c}3,6 \pm \\
0,37\end{array}$ & $\begin{array}{l}\text { Alto Paranaíba, Minas } \\
\text { Gerais, Brazil }\end{array}$ & $\begin{array}{l}\text { Summer/Dece } \\
\text { mber to March }\end{array}$ & $\begin{array}{l}\text { T and RH; Sow: FI; } \\
\text { weight loss at lactation, } \\
\text { WEI; Piglets: weight at } 14 \\
\text { and } 20 \text { days old }\end{array}$ \\
\hline $\begin{array}{l}\text { Justino et al. } \\
(2014)\end{array}$ & $\begin{array}{l}\text { Lactating } \\
\text { sows }\end{array}$ & 36/DanBred ${ }^{\circledR}$ & 1 to 5 & $\begin{array}{c}\text { In Southwestern Brazil } \\
\left(18^{\circ} 1700^{\prime \prime} \mathrm{S}, 146^{\circ} 59^{\prime}\right. \\
\left.36^{\prime \prime} \mathrm{W}\right)\end{array}$ & Summer/NSP & $\begin{array}{c}\mathrm{T}, \mathrm{RH} \text { and } \mathrm{AV} ; \\
\text { physiological parameters: } \\
\mathrm{RT}, \mathrm{ST}, \mathrm{RR} \text { and sensible } \\
\text { heat change at lactation }\end{array}$ \\
\hline $\begin{array}{l}\text { Wang et al. } \\
\text { (2014) }\end{array}$ & $\begin{array}{l}\text { Lactating } \\
\text { sows }\end{array}$ & $32 * / \mathrm{NSP}$ & NSP & $\begin{array}{l}\text { Zhejiang Province } \\
\text { China }\end{array}$ & Summer/NS & T, AV, RH; Sow: RR \\
\hline $\begin{array}{l}\text { Justino et al. } \\
(2015)\end{array}$ & $\begin{array}{l}\text { Lactating } \\
\text { sows }\end{array}$ & 18/Danbred & 1 to 5 & $\begin{array}{c}18^{\circ} 17^{\prime} 00^{\prime \prime} \mathrm{S}, 46^{\circ} 59^{\prime} 36^{\prime \prime} \\
\text { W and average altitude } \\
\text { of } 972 \mathrm{~m}\end{array}$ & $\begin{array}{c}\text { Summer/Janua } \\
\text { ry to March of } \\
2010\end{array}$ & $\begin{array}{c}\text { Sow: RR; RT; ST; FI; } \\
\text { body condition (BW and } \\
\text { BFT); WEI; Piglets: } \\
\text { BWW and mortality }\end{array}$ \\
\hline $\begin{array}{l}\text { Lontoc et al. } \\
(2016)\end{array}$ & $\begin{array}{l}\text { Gestating } \\
\text { sows }\end{array}$ & Min 42/NSP & NSP & Rizal Province & $\begin{array}{l}\text { Summer/Febru } \\
\text { ary to June of } \\
2014\end{array}$ & $\begin{array}{l}\text { THI; Sow: BFT at } \\
\text { farrowing and weaning; } \\
\text { WEI; pregnancy period; } \\
\text { litter size at weaning; } \\
\text { PBW, BWW, NTB and } \\
\text { mortality }\end{array}$ \\
\hline $\begin{array}{l}\text { Botto et al. } \\
(2014)\end{array}$ & $\begin{array}{l}\text { Gestating } \\
\text { sows }\end{array}$ & 60/NSP & NSP & Not specified & Summer/NSP & $\begin{array}{c}\text { T; RH; AV; THI; } \\
\text { Comprehensive climate } \\
\text { index }\end{array}$ \\
\hline $\begin{array}{l}\text { Perin et al. } \\
(2016)\end{array}$ & $\begin{array}{l}\text { Lactating } \\
\text { sows/litter }\end{array}$ & $\begin{array}{l}\text { 128/Landrace } \\
\text { x Large White } \\
\text { / Duroc }\end{array}$ & 1 to 8 & $\begin{array}{c}\text { Santa Catarina, Brazil } \\
\left(26^{\circ} 22^{\prime} 13^{\prime} \mathrm{S} \text { and }\right. \\
\left.50^{\circ} 08^{\prime} 40 \mathrm{~W}\right)\end{array}$ & $\begin{array}{l}\text { Summer/Janua } \\
\text { ry and } \\
\text { February of } \\
2011\end{array}$ & $\begin{array}{l}\text { Sow: weight loss at } \\
\text { lactation; FI; FR; WEI; } \\
\text { farrowing rate; NTB }\end{array}$ \\
\hline $\begin{array}{l}\text { Chen et al. } \\
(2018)\end{array}$ & $\begin{array}{l}\text { Gestating / } \\
\text { lactating } \\
\text { sows }\end{array}$ & $\begin{array}{l}\text { 28/Landrace } \times \\
\text { Yorkshire }\end{array}$ & $\begin{array}{l}\text { Multipar } \\
\text { ous }\end{array}$ & $\begin{array}{l}\text { Guangdong Province in } \\
\text { South China }\end{array}$ & $\begin{array}{l}\text { NS/august and } \\
\text { october of } \\
2015\end{array}$ & $\begin{array}{c}\text { FI during lactation; NTB } \\
\text { per litter; NBA; S; litter } \\
\text { weight and average } \\
\text { weight of the piglets; } \\
\text { NWP }\end{array}$ \\
\hline
\end{tabular}

Environmental variables: T - ambient temperature; RH - relative humidity; AV - air velocity; BGHI - black globe temperature and humidity index; THI - temperature and humidity index; RTL - radiant thermic load. Sows: BW - body weight; BFT - backfat thickness; LD - loin depth; RR - respiratory rate; ST - surface temperature; RT - rectal temperature; FI - feed intake; WEI - weaning-to-estrus interval; FR - farrowing rate. Piglets: NTB - number of total born piglets; NBA - number of piglets born alive; S - Stillbirths; NWP number of weaned piglets; PBW - weight of the piglets at birth; BWW - weight of piglet at weaning; GPD - daily weight gain.

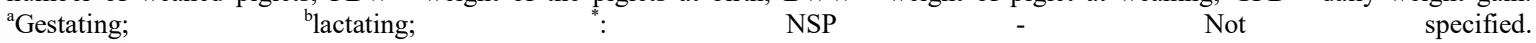

studies already available. In animal science, the use of systematic review produces new scientific information, avoiding unnecessary repetition of experiments on animals (POUND \& RITSKES-HOITINGA, 2020).
The systematic reviews constitute an important way to broaden the view on a given topic, in order to evaluate the progress of the studies over the years, allowing the emergence of new questions 
Table 4 - Effect of the use of the evaporative cooling system on the environmental variables of the barns for sows.

\begin{tabular}{|c|c|c|c|c|}
\hline Author/year & $\mathrm{A}$ & $\mathrm{B}$ & $\mathrm{C}$ & $\mathrm{D}$ \\
\hline & ${ }^{\circ} \mathrm{C}$ & $\%$ & $\mathrm{~m} \mathrm{~s}^{-1}$ & points \\
\hline Turco et al. (1998) & NSP & NS & $\mathrm{NE}$ & NS \\
\hline Romanini et al. (2008) & NS & $>17.5$ & $\mathrm{NE}$ & $\mathrm{NE}$ \\
\hline Kiefer et al. (2012) & NSP & NSP & NSP & NSP \\
\hline Morales et al. (2013) & NS & $>0.9$ & NE & $\mathrm{NE}$ \\
\hline Justino et al. (2014) & $<2.1$ & $>9.7$ & $>3.15$ & $\mathrm{NE}$ \\
\hline Wang et al. (2014) & $\mathrm{NE}$ & $\mathrm{NE}$ & NE & NE \\
\hline Justino et al. (2015) & $<2.1$ & $>9.7$ & $\mathrm{NE}$ & ITU: $<3.10$ \\
\hline Lontoc et al. (2016) & $<\mathrm{NSP}$ & NSP & $\mathrm{NE}$ & ITU: $<2.15$ \\
\hline Botto et al. (2014) & $<2.9$ & $>18.5$ & NS & ITU: $<0.90$ \\
\hline Perin et al. (2016) & NE & NE & $\mathrm{NE}$ & NE \\
\hline Chen et al. (2018) & $<\mathrm{NSP}$ & $>$ NSP & $\mathrm{NE}$ & ITU: $<$ NSP \\
\hline
\end{tabular}

A: Internal temperature of the barn; B: Internal relative humidity of the barn; C: Internal velocity of air; D: Indexes; NE: not evaluated for when a certain variable was not evaluated in the study; NS: not significant; NSP: not specified - for when the authors performed the analysis or measurement of a certain variable; however, the result was not shown in the published study.

by the scientific community. In this review, it was sought to ensure that all scientific papers related to the theme were present. However, papers not related to the keywords used or that did not fit the established criteria were disregarded as recommended in the literature (SILVA et al., 2014).

The papers selected to compose the systematic review were concentrated between the years 2008 and 2018 probably due to changes in related to the yield of modern sows, which became more sensitive to high temperatures (CABEZÓN et al., 2017). This justifies the need for studies about adaptations in relation to the thermal environment of the barns, among them the evaporative cooling system is shown as an alternative. Modern architectural designs within pig production must be idealized to keep animals in their thermal comfort, known as the thermoneutral zone in which maximum efficiency is achieved, an example is increased milk yield when a lactating sow is in thermal comfort.

Table 5 - Effect of the use of evaporative cooling system on the physiological parameters of sows.

\begin{tabular}{|c|c|c|c|c|}
\hline Author/year & Category & A & $\mathrm{B}$ & $\mathrm{C}$ \\
\hline & & ${ }^{\circ} \mathrm{C}$ & ${ }^{\circ} \mathrm{C}$ & movements/minute \\
\hline Turco et al. (1998) & Lact & NSP & $\mathrm{NE}$ & NSP \\
\hline Romanini et al. (2008) & Lact & $\mathrm{NE}$ & NS & $<4.20$ \\
\hline Kiefer et al. (2012) & Lact & $\mathrm{NE}$ & $\mathrm{NE}$ & NE \\
\hline Morales et al. (2013) & Lact & $\mathrm{NE}$ & $\mathrm{NE}$ & $\mathrm{NE}$ \\
\hline Justino et al. (2014) & Lact & NS & $<0.5$ & $<15.87$ \\
\hline Wang et al. (2014) & Lact & $\mathrm{NE}$ & $\mathrm{NE}$ & $>$ than ideal \\
\hline Justino et al. (2015) & Lact & $<0.3$ & $<0.5$ & $<23.67$ \\
\hline Lontoc et al. (2016) & Gestating & $\mathrm{NE}$ & $\mathrm{NE}$ & NE \\
\hline Botto et al. (2014) & Gestating & NE & $\mathrm{NE}$ & $\mathrm{NE}$ \\
\hline Perin et al. (2016) & Lact & $<\mathrm{NSP}$ & $\mathrm{NE}$ & $\mathrm{NE}$ \\
\hline Chen et al. (2018) & Gestating and Lact & NE & $\mathrm{NE}$ & NE \\
\hline
\end{tabular}

A: Rectal temperature; B: Surface temperature; C: Respiratory rate; NE: not evaluated - for when a certain variable was not evaluated in the study; NS: not significant; NSP: not specified - for when the authors performed the analysis or measurement of a certain variable; however, the result was not shown in the published study; Lact: Lactating. 
To minimize the effects of thermal stress over the performance and yield of sows, it is possible to adopt technologies that allow the strategic management. The evaporative cooling system can be presented in two ways, with plates positioned to cool the macro environment or direct the air through tubes to the cervical region of the sow (more used for lactating sows) in order to modify the microenvironment. During lactation it is necessary to guarantee lower temperatures to the sow, reducing heat stress. However, higher temperatures are important to better guarantee the piglet development, which justifies the use of tubes directed only to sows.

The use of evaporative cooling systems aims to reduce the room temperature inside the facilities, providing greater thermal comfort to the animals and minimizing the effects of heat on physiological and performance parameters. Effects observed with the use of evaporative cooling are shown in table 4, 5 and 6 . Evaporative cooling systems when well managed can reduce the barn's internal temperature by up to $10.0^{\circ} \mathrm{C}$, depending on the weather conditions in the region. For being based on the principle of changing the physical state of water to decrease dry bulb temperature, this system becomes efficient in places of hot and dry climate. According to the researches, it was found that the use of this system reduced the internal temperature of the facilities by up to $2.9^{\circ} \mathrm{C}$ in a scenario of external temperatures varying between $23.4{ }^{\circ} \mathrm{C}$ and $33.3{ }^{\circ} \mathrm{C}$ and relative humidity ranging between 36 and $76 \%$. Evaporative cooling systems have the potential to decrease the room temperature between 5.0 and $7.0{ }^{\circ} \mathrm{C}$ inside barns, but this depends on the external temperature and relative humidity (LUCY \& SAFRANSKI, 2017).

As a consequence of the use of the evaporative cooling system, there is naturally an increase in the relative humidity inside the facilities. This was observed in all studies that evaluated this parameter. The lowest value was reported by MORALES et al. (2013), representing an increase of $0.9 \%$ (73.6 to $74.5 \%$ ), while BOTTO et al. (2014) observed an increase of approximately $19 \%$ (48.7 to $67.2 \%$ ). It is worth noting that environments with high air temperature and relative humidity restrict heat losses by airways in the pig, which tends to decrease the animals' feed intake and consequently affect their performance (NOBLET et al., 2003).

In this way it is found that the increase of humidity is acceptable in regions with hot and dry climates, but in humid regions, there is a need for greater ventilation, to reduce the adverse effects of the internal humidity of the facilities. Maintenance of relative humidity at the indicated levels ensures an adequate water vapor pressure gradient for evaporative heat loss and establishes the thermal

Table 6 - Effect of the evaporative cooling system on the sows' performance.

\begin{tabular}{|c|c|c|c|c|c|c|c|c|c|c|}
\hline Author/year & Category & A & B & $\mathrm{C}$ & $\mathrm{D}$ & $\mathrm{E}$ & $\mathrm{F}$ & G & $\mathrm{H}$ & I \\
\hline & & $\mathrm{kg} \mathrm{d}^{-1}$ & $\mathrm{~mm} \mathrm{BFT}^{1} / \% \operatorname{lost}^{2}$ & day & $\%$ & $\mathrm{n}$ & $\mathrm{n}$ & $\mathrm{kg}$ & $\%$ & $\%$ \\
\hline Turco et al. (1998) & Lact. & NE & NS & $\mathrm{NE}$ & $\mathrm{NE}$ & NS & $\mathrm{NE}$ & $\mathrm{NE}$ & NS & $\mathrm{NE}$ \\
\hline Romanini et al. (2008) & Lact. & $\mathrm{NE}$ & $>0.40^{1}$ & $\mathrm{NE}$ & $\mathrm{NE}$ & $\mathrm{NE}$ & $\mathrm{NE}$ & $\mathrm{NE}$ & NS & $\mathrm{NE}$ \\
\hline Kiefer et al. (2012) & $\begin{array}{c}\text { Lact. P } 1 \text { and } 2 \\
\text { Lact. P } 3 \text { to } 8\end{array}$ & $\begin{array}{l}>1.67 \\
>1.15\end{array}$ & $\begin{array}{l}<7.92^{2} \\
<6.54^{2}\end{array}$ & $\mathrm{NE}$ & $\begin{array}{l}>18.8 \\
>13.3\end{array}$ & $\mathrm{NE}$ & $\mathrm{NE}$ & $\mathrm{NE}$ & $\begin{array}{l}>21.80 \\
>10.98\end{array}$ & NS \\
\hline Morales et al. (2013) & Lact. & $>0.40$ & NS & NS & $\mathrm{NE}$ & $\mathrm{NE}$ & $\mathrm{NE}$ & $\mathrm{NE}$ & NS & $\mathrm{NE}$ \\
\hline Justino et al. (2014) & Lact. & NE & $\mathrm{NE}$ & $\mathrm{NE}$ & $\mathrm{NE}$ & $\mathrm{NE}$ & $\mathrm{NE}$ & $\mathrm{NE}$ & NE & $\mathrm{NE}$ \\
\hline Wang et al. (2014) & Lact. & $\mathrm{NE}$ & $\mathrm{NE}$ & $\mathrm{NE}$ & $\mathrm{NE}$ & $\mathrm{NE}$ & $\mathrm{NE}$ & $\mathrm{NE}$ & $\mathrm{NE}$ & $\mathrm{NE}$ \\
\hline Justino et al. (2015) & Lact. & NS & NS & NS & $\mathrm{NE}$ & $\mathrm{NE}$ & $\mathrm{NE}$ & NS & $>3.35$ & NS \\
\hline Lontoc et al. (2016) & Gestating & $>\mathrm{NSP}$ & $>2.31^{1}$ & $<0.8$ & $\mathrm{NE}$ & NS & NS & NE & NS & NS \\
\hline Botto et al. (2014) & Gestating & NE & $\mathrm{NE}$ & $\mathrm{NE}$ & $\mathrm{NE}$ & $\mathrm{NE}$ & $\mathrm{NE}$ & $\mathrm{NE}$ & $\mathrm{NE}$ & $\mathrm{NE}$ \\
\hline Perin et al. (2016) & $\begin{array}{c}\text { Lact. P } 1 \\
\text { Lact. P >1 }\end{array}$ & $\begin{array}{l}>1.10 \\
>1.00\end{array}$ & $<3.10^{2}$ & $\begin{array}{l}<3.8 \\
<0.3\end{array}$ & $\mathrm{NE}$ & $\mathrm{NE}$ & $\mathrm{NE}$ & $\mathrm{NE}$ & $>7.04$ & $\mathrm{NE}$ \\
\hline Chen et al. (2018) & Gestating and Lact. & NS & $\mathrm{NE}$ & NE & $\mathrm{NE}$ & NS & NS & NS & NS & $\mathrm{NE}$ \\
\hline
\end{tabular}

A: feed intake; B: body condition ( ${ }^{1}$ backfat thickness and/or ${ }^{2}$ weight loss at lactation); C: weaning-to-estrus interval; D: milk yield by the sow $\left(\mathrm{kg} \mathrm{d}^{-1}\right)$; E: total number of piglets born; F: number of piglets born alive; G: weight of the piglet at birth total; H: weight of the piglet or of the litter at weaning; I: mortality of piglet; NE: not evaluated - for when a certain variable was not evaluated in the study; NS: not significant; NSP not specified - for when the authors performed the analysis or measurement of a certain variable; however, the result was not shown in the published study; P: parity; Lact.: Lactating. 
gradient as the primary factor affecting heat transfer (WILLIAMS et al., 2013). According to SAMPAIO et al. (2004), for swine, the average relative humidity inside the barn should not exceed $70 \%$ in order not to interfere in the heat loss through evaporation.

Ventilation plays an extremely important role in animal production; this influences in the heat dissipation of the facilities, as well as in the reduction of the concentration of vapors, smoke, dust and toxic gases to production. However, this was specified in only two studies, with an increase of $0.06 \mathrm{~m} \mathrm{~s}^{-1}$ with the use of the negative pressure evaporative cooling system (BOTTO et al., 2014) and $3.15 \mathrm{~m} \mathrm{~s}^{-1}$ with the use of the ductofan evaporative cooling system (JUSTINO et al., 2014). In a study that evaluated combinations of air velocity and ambient temperature for growing pigs, a higher temperature and lower air velocity contributed to lower growth rate and higher microbiological load in the bays. At an internal temperature of $28.0{ }^{\circ} \mathrm{C}$, the air velocity should be in the range of 0.74 to $1.31 \mathrm{~m} \mathrm{~s}^{-1}$ (SALLVIK \& WALBERG, 1984).

High ventilation rates are required to produce air velocity, which may have a cooling effect during periods of high temperature, especially when the skin of the pig is moist and water evaporates (BANHAZI et al., 2008). Heat dissipation occurs through the convection mechanism, a process of heat transfer between the animal and the environment through a fluid (e.g. wind). Thus, ventilation is important in production systems due to the reduced impact caused by heat.

With respect to the bioclimatic index, in $36 \%$ of the articles, the temperature and humidity index was measured and only in one study, which makes up $8 \%$, the black globe temperature and humidity index was evaluated. The greater use of temperature and humidity index may be due to the greater volume of data available in the literature related to this bioclimatic index or the absence of an instrument (black globe) in the bioclimatic evaluation during the experiments. It was observed that the use of the cooling system allowed a reduction of temperature and humidity index by up to 3.1 scores (77.2 to 74.1) (JUSTINO et al., 2015). The effect of the evaporative cooling system on the black globe temperature and humidity index was evaluated in the research of TURCO et al. (1998), resulting in a higher value of than the upper critical limit for lactating sows, considered 72 by the same authors.

The use of evaporative cooling allowed a reduction of $0.3{ }^{\circ} \mathrm{C}\left(39.0\right.$ to $\left.38.7{ }^{\circ} \mathrm{C}\right)$ in the rectal temperature of the animals of one of the studies, and of $0.5^{\circ} \mathrm{C}\left(34.8\right.$ to $\left.34.3^{\circ} \mathrm{C}\right)$ in the surface temperature, being these data reported in the papers of JUSTINO et al. (2014) and JUSTINO et al. (2015), respectively. Rectal temperature is an important indicator of when the pig exceeds thermoregulatory capacity. When the temperature increases, the gradient between the rectal temperature and surface temperature decreases, with the purpose of reestablishing the homeostasis (QUINIOU \& NOBLET, 1999). MUNS et al. (2016) when evaluating sows subjected to $25^{\circ} \mathrm{C}$ close to calving, they observed an increase in the surface temperature of the mammary gland, as a strategy to deal with high temperature by increasing blood flow to the skin.

Heat stress is one of the major concerns in pig production during the summer season, as these animals do not have functional sweat glands like other animal species to help them remove body heat efficiently. In addition, the more heat an animal produces internally by its metabolism, the lower its ability to tolerate the heat of the environment (ZHANG et al., 2011). MALMKVIST et al. (2012) observed an increase in rectal temperature (38.0 to $39.0{ }^{\circ} \mathrm{C}$ ), surface temperature $\left(36.7\right.$ to $\left.34.3^{\circ} \mathrm{C}\right)$ and respiratory rate (29 to 58 movements per minute) when the temperature increased from 15.0 to $25.0{ }^{\circ} \mathrm{C}$.

The respiratory rate is indicated as the most sensitive indicator of heat stress for sows, being more representative than body temperature (LUCY \& SAFRANSKI, 2017) is also the first physiological indicator of the animal response at high temperature (BANHAZI et al., 2008). This parameter was evaluated in $36 \%$ of the studies and respiratory rate reduction was observed with the use of cooling. As pigs are not efficient at dissipating heat through evaporation by the skin, they depend on the efficacy of this mechanism. When the respiratory rate is high, temperature is presumed to be close to body temperature, heat is not lost, and body temperature rises above normal values. This occurs due to the lower thermal gradient between the external body temperature and the temperature of the ambient. This response is due to direct stimulation in the heat center in the hypothalamus that sends impulse to the cardiorespiratory system in an attempt to eliminate heat by evaporation through respiration, which in this case shows a remarkable increase (PANDORFI et al., 2008). According to RIBEIRO et al. (2018), lactating sows kept under heat conditions showed an increase of 44 movements per minute (50 to 94 movements per minute) in respiratory rate and an increase of $0.5{ }^{\circ} \mathrm{C}\left(35.8\right.$ to $\left.36.3{ }^{\circ} \mathrm{C}\right)$ in the rectal temperature. The authors who observed the 
increase in respiratory rate emphasized that this was not sufficient to maintain homeothermia and that physiological hyperthermia occurred.

Most of the studies evaluated the system in lactating sows; this category is pointed out as the most sensitive to heat, being observed, for example, greater increase in rectal temperature in lactating sows submitted to hot environments when compared to gestating sows (WILLIAMS et al., 2013). The choice of which barn to cool depends on the economic impact of when heat mitigation strategies are not used, the economic losses depend on the magnitude of the effect on performance, which can be assessed through controlled studies (LUCY \& SAFRANSKI, 2017). The genetic improvement of the commercial strains, especially of the strains of sows, allowed the increase of production and the sows became more demanding metabolically, mainly when gestating or lactating. Higher yield implies high thermogenesis as compared to sows from more ancient strains, which resulted in higher environmental requirements with reduction of the upper critical temperature (BROWNBRANDL et al., 2014; STINN \& XIN, 2014; CABEZÓN et al., 2017).

As reported in the results of the review, in $55 \%$ of the studies, cooled air was directed onto the cervical region and head of the lactating sows. This type of cooling is related to the fact that there are two categories in the same facilities: the sow and the suckling piglets. For lactating sows, the ideal temperature range varies from 12 to $15{ }^{\circ} \mathrm{C}$, while piglets require 28 to $35{ }^{\circ} \mathrm{C}$ between 0 and 14 days of age (FERREIRA, 2016). If the temperature is below the inferior critical temperature for piglets, its growth rate is compromised (BLACK et al., 1993) and may cause increased energy expenditure to maintain body temperature, hampering its development until weaning.

In addition to thermal environment parameters, those of performance and physiological were used to infer the influence of the use of the evaporative cooling system. The values observed with the measurement of some environmental variables were not specified in some studies, which make difficult to interpret the changes promoted by the system in the barns. The physiological variables were evaluated in a smaller portion of the researches $(45 \%)$, possibly because of the greater difficulty in measuring or ignoring the relationship between the physiological parameters and the environment by the authors at the time of the project execution. By means of physiological variables, changes that potentially influence the performance are noticed.
The environment may influence the reproductive performance of the sow during the gestation period and consequently the quality of the litter with regard to the number of total and live births, birth weight, variability and incidence of intrauterine growth retardation. In that way, more than half of the studies evaluated variables related to litter. Gestating sows when submitted to heat stress may have compromised embryonic development. In the first third of gestation, the sow is more sensitive to heat (AUVIGNE et al., 2010), a fact that can impact the number of total born piglets that is defined in this period. In the other periods of gestation, heat stress may impact on other performance indexes such as birth weight, number of piglets born alive, and incidence of stillbirths.

Heat tolerance and the effect of temperature on fertility appear to be genetically influenced. Possible damages in gestating sows exposed to heat stress are reported in the literature, such as increased embryonic mortality (WILDT et al., 1975; BLOEMHOF et al., 2013), increase of the number of stillborn piglets (OMTVEDT et al., 1971), decrease of the birth weight (WEGNER et al., 2016), besides economic losses due to poorer performance. The selection of sows for better farrowing rates contributed to increase the susceptibility to heat stress, as perceived by decreasing litter size and number of piglets born (BLOEMHOF et al., 2008).

In the studies selected in which the performance at farrowing was evaluated, no influence of the use of cooling system during pregnancy on the number of total born piglets, number of piglets born alive and weight of the piglets at birth was reported. However, it is known that heat stress can harm offspring. MUNS et al. (2016) reported a reduction in feed intake by sows subjected to heat stress, with impaired on piglet weight at weaning, which may be due to less milk production. In the studies evaluated by the systematic review, the sows in question were not effectively subjected to heat stress, which did not have a negative effect on the litter at farrowing.

In the lactating sow, feed consumption presents itself as a challenge in the production system and in case of a thermal load, the immediate reduction in the intake of nutrients is observed as an early response, presumably a strategy to reduce the metabolic heat generated in the digestion process (BAUMGARD \& RHOADS, 2013), which explains the observed decrease in the consumption of heatsubmitted sows. The feed intake of the lactating sows in this review was positively influenced by the use of the evaporative cooling system, among 
the studies that evaluated it, only one did not find any improvement in feed intake. This is due to the decrease in the temperature of the maternity barns achieved with the use of the cooling system in order to approach the temperature and humidity of the range determined as ideal for this category, which would be temperature ranging between 16.0 and $22.0{ }^{\circ} \mathrm{C}$ and the ideal relative humidity of 40 to $70 \%$ (BRAGANÇA et al., 1998).

In addition to the direct effects, heat stress can compromise milk performance through reduced milk yield. Peripheral vasodilation occurs in order to dissipate body heat. In this way, dietary nutrients and those mobilized from body reserves are diverted from the mammary gland, affecting milk yield (RENAUDEAU et al., 2003). In a meta-analytical study, there was a negative correlation between increase at room temperature (above the thermal comfort range of 15.0 to $25.0{ }^{\circ} \mathrm{C}$ ), and the feed intake and milk production of lactating sows and weaning weight of the piglets (RIBEIRO et al., 2018).

In spite of milk production having been evaluated in only one study, its increase is a factor that may explain the greater weight of piglets at weaning observed in studies in which improvement of the thermal environment occurs during lactation (RENAUDEAU \& NOBLET, 2001). According to CABEZON et al. (2017) for sows to achieve a high percentage of their genetic potential for milk production and to minimize weight loss during lactation, a part of the excess heat produced must be removed.

The body condition of the sow at the time of weaning is related to several factors such as body condition at the time of farrowing and feed intake during the lactation period. With the review, it was observed that the feed intake was improved when using the cooling system, agreeing with those of body condition in which the use of cooling allowed smaller losses. ROMANINI et al. (2008) demonstrated that sows submitted to forced ventilation or evaporative cooling showed a greater backfat thickness (14.9 $\mathrm{mm})$ relative to natural ventilation $(14.5 \mathrm{~mm})$.

Studies related to weaning-to-estrus interval reported no direct relation between this index and the room temperature. RENAUDEAU et al. (2003) did not find effects of the ambient temperature $\left(20.0\right.$ or $\left.29.0^{\circ} \mathrm{C}\right)$ on the weaning-to-estrus interval.

The use of the system allowed the reduction of the weaning-to-estrus interval only in one study. Prolonged weaning intervals in swine sows may be associated with increased body wear in these sows, as a consequence of the greater mobilization of body reserves. For BERTOLDO et al. (2011), summer heat stress causes infertility in sows with longer interval of days between weaning and estrus, longer anestrous period, low fertility, higher percentage of return of estrus due to the poor conception rate and subsequent farrowing with smaller numbers of piglets per litter.

In general, the evaporative cooling system promoted improvements in the thermoregulatory conditions of lactating sows an; consequently, in the performance of the piglets. In addition, there was a greater number of scientific studies that evaluate the use of this cooling system for lactating sows than for gestating sows.

\section{CONCLUSION}

Use of evaporative cooling system promoted increase in feed intake per lactating sow, decrease in weight loss in lactation, increase of weight of piglets at weaning, reduction of the temperature of the barns and decrease of the respiratory rate of the sows. For gestating sows, no changes in reproductive performance were reported.

\section{ACKNOWLEDGEMENTS}

To the Coordenação de Aperfeiçoamento de Pessoal de Nível Superior (CAPES) for granting a scholarship.

\section{DECLARATION OF CONFLICTS OF INTERESTS}

The authors declare no conflict of interest. The founding sponsors had no role in the design of the study; in the collection, analyses, or interpretation of data; in the writing of the manuscript, and in the decision to publish the results.

\section{AUTHORS' CONTRIBUTIONS}

All authors contributed equally to the planning and writing of the manuscript. All authors critically reviewed the manuscript and approved a final version.

\section{REFERENCES}

AUVIGNE, V. et al. Seasonal infertility in sows: A five year field study to analyze the relative roles of heat stress and photoperiod. Theriogenology, v.74, p.60-66, 2010. Available from: <https://www.sciencedirect.com/science/article/abs/pii/ S0093691X10000567>. Accessed: May, 20, 2019. doi: 10.1016/j. theriogenology.2009.12.019.

BANHAZI, T. M. et al. Review of issues related to heat stress in intensively housed pigs. American Society of Agricultural and Biological Engineers, v.7, p.737-744, 2008. Available from: $<$ https://www.cabdirect.org/cabdirect/abstract/20103078665>. Accessed: May, 20, 2019. doi: 10.13031/2013.25578. 
BAUMGARD, L. H.; RHOADS, R. P. Effects of heat stress on post absorptive metabolism andenergetics. Annual Review of Animal Biosciences, v.1, p.311-337. 2013. Available from: $<$ https://www.annualreviews.org/doi/abs/10.1146/annurevanimal-031412-103644>. Accessed: May, 12, 2019. doi: 10.1146/ annurev-animal-031412-103644.

BERTOLDO, M. J. et al. Seasonal effects on oocyte developmental competence in sows experiencing pregnancy loss. Animal Reproduction Science, v.124, p.104-111, 2011. Available from: $\quad<\mathrm{https} / / / \mathrm{www}$. sciencedirect.com/science/article/pii/ S0378432011000510>. Accessed: May, 23, 2019. doi: 10.1016/j. anireprosci.2011.02.012.

BLACK, J. L. et al. Lactation in the sow during heat stress Livestock Production Science, v.35, p.153-170, 1993 Available from: <https://www.sciencedirect.com/science/ article/pii/030162269390188N $>$. Accessed: May, 19, 2019. doi: $10.1016 / 0301-6226(93) 90188-\mathrm{N}$.

BLOEMHOF, S. et al. Sow line differences in heat stress tolerance expressed in reproductive performance traits. Journal of Animal Science, v.86, p.3330-3337, 2008. Available from: <https:// academic.oup.com/jas/article/86/12/3330/4790101/>. Accessed: May, 23, 2019. doi: 10.2527/jas.2008-0862.

BLOEMHOF, S. et al. Effect of daily environmental temperature on farrowing rate and total born in dam line sows. Journal of Animal Science, v.91, p.2667-2679, 2013. Available from: <https:// academic.oup.com/jas/article-abstract/91/6/2667/4717192/> Accessed: May, 23, 2019. doi: 10.2527/jas.2012-5902.

BOTTO, L. et al. The effect of evaporative cooling on climatic parameters in a stable for sows. Research in Agricultural Engineering, v.60, p.S85-S91, 2014. Available from: <https://www.agriculturejournals.cz/web/rae htm?type $=$ article\&id $=40 \_2013-\mathrm{RAE}>$. Accessed: May, 11, 2019. doi: $10.17221 / 40 / 2013-R A E$.

BRAGANÇA, M. M. et al. Does feed restriction mimic the effects of increased ambient temperature in lactating sows. Journal of Animal Science, v.76, p.2017-2024, 1998. Available from: $<$ https://academic.oup.com/jas/article/76/8/2017/4643221/>. Accessed: May, 22, 2019. doi: 10.2527/1998.7682017x.

BROWN-BRANDL, T. M. et al. Heat and moisture production in modern swine. ASHRAE Transactions, v.120, p.469-489, 2014. Available from: <https://lib.dr.iastate.edu/abe eng conf/534/> Accessed: May, 21, 2019.

CABEZÓN, F.A. et al. Effect of floor cooling on late lactation sows under acute heat stress. Livestock Science, v.206, p.113-120, 2017. Available from: <https://www.sciencedirect.com/science/ article/abs/pii/S1871141317303098>. Accessed: May, 08, 2019. doi: 10.1016/j.livsci.2017.10.017.

CHEN, J. et al. Effect of pad-fan cooling and dietary organic acid supplementation during late gestation and lactation on reproductive performance and antioxidant status of multiparous sows in hot weather. Tropical Animal Health and Production, v.50, p.973-982, 2018. Available from: <https://link.springer.com/ article/10.1007/s11250-018-1520-z>. Accessed: May, 15, 2019. doi: $10.1007 / \mathrm{s} 11250-018-1520-\mathrm{z}$.

CROSS, A. J. et al. Genome-wide association of changes in swine feeding behaviour due to heat stress. Genetics Selection
Evolution, v.50, p.1-12, 2018. Available from: $<$ https://gsejournal. biomedcentral.com/track/pdf/10.1186/s12711-018-0382-1>. Accessed: May, 08, 2019. doi: 10.1186/s12711-018-0382-1.

FERREIRA, M. S. S. et al. Effect of ractopamine on lipid metabolism in vivo - A systematic review. Brazilian Archives of Biology and Technology, v.56, p.35-43, 2013. Available from: <http://www. scielo.br/scielo.php?pid=S1516-89132013000100005\&script=sci arttext\&tlng=es>. Accessed: May, 07, 2019. doi: 10.1590/S151689132013000100005 .

FERREIRA, R. A. Maior Produção com Melhor Ambiente para Aves, Suínos e Bovinos. 3 ed. Viçosa: Aprenda Fácil, 2016. 528p.

HILBRANDS, A. M. et al. Research room design using artificial heat sources to implement heat stress studies of pigs. Applied Engineering in Agriculture, v.33, p.881-889, 2017. Available from: <https:// elibrary.asabe.org/abstract.asp?aid=48639>. Accessed: May, 08, 2019. doi: $10.13031 /$ aea. 12398 .

JUSTINO, E. et al. The impact of evaporative cooling on the thermoregulation and sensible heat loss of sows during farrowing. Engenharia Agrícola, v.34, p.1050-1061, 2014. Available from: <http://www.scielo.br/scielo.php?pid=S0100$69162014000600003 \&$ script $=$ sci_arttext\&tlng $=\mathrm{pt}>$. Accessed: May, 15, 2019. doi: 10.1590/S0100-69162014000600003.

JUSTINO, E. et al. Effect of evaporative cooling and electrolyte balance on lactating sows in tropical summer conditions. Arquivo Brasileiro de Medicina Veterinária e Zootecnia, v.67, p.455-464, 2015. Available from: <http://www.scielo.br/ scielo.php?pid=S0102-09352015000200455\&script=sci_arttext $>$. Accessed: May, 15, 2019. doi: 10.1590/1678-6478.

KIEFER, C. et al. Evaporative cooling for lactating sows under high ambient temperature. Revista Brasileira de Zootecnia, v.41, p.1180-1185, 2012. Available from: <http://www.scielo. br/scielo.php?pid=S1516-35982012000500015\&script $=$ sci arttext\&tlng=es $>$. Accessed: May, 16, 2019. doi: 10.1590/S151635982012000500015 .

LONTOC, C. A. A. et al. Comparative performance of sows housed with and without evaporative cooling system at temperature humidity index of 73-83. Philippine Journal of Veterinary and Animal Sciences, v.42, p.77-84, 2016. Available from: <http:// pjvas.org/index.php/pjvas/article/viewFile/183/164>. Accessed: May, 08, 2019.

LUCY, M. C.; SAFRANSK, T. J. Heat stress in pregnant sows: Thermal responses and subsequent performance of sows and their offspring. Molecular Reproduction and Development, v.84, p.1-11, 2017. Available from: <https://onlinelibrary.wiley. com/doi/full/10.1002/mrd.22844>. Accessed: May, 19, 2019. doi: $10.1002 / \mathrm{mrd} .22844$.

MALMKVIST, J. et al. Influence of thermal environment on sows around farrowing and during the lactation period. Journal of Animal Science, v.90, p.3186-3199, 2012. Available from: $<$ https:// academic.oup.com/jas/article-abstract/90/9/3186/4701725/>. Accessed: May, 14, 2019. doi: 10.2527/jas.2011-4342.

MORALES, O. E. S. et al. Effect of different systems for the control of environmental temperature on the performance of sows and their litters. Acta Scientiae Veterinariae, v.41, p.1-7, 2013. Available from: <https://www.redalyc.org/pdf/2890/289031817016.pdf>. Accessed: May, 14, 2019. 
MUNS, R. et al. High environmental temperature around farrowing induced heat stress in crated sows. Journal of Animal Science, v.94, p.377-384, 2016. Available from: <https://academic.oup. $\mathrm{com} /$ jas/article-abstract/94/1/377/4701077?redirectedFrom=fullte xt>. Accessed: Jan. 22, 2020. doi: 10.2527/jas.2015-9623.

NOBLET, J. et al. Estimation de la valeur énergétique des aliments pour le porc. Productions Animales, v.3, p.197-210, 2003. Available from: <http://agris.fao.org/agris-search/search. do? recordID=LV2016020035>. Accessed: May, 19, 2019.

OMTVEDT, I. T. et al. Influence of heat stress during early, mid and late pregnancy of gilts. Journal of Animal Science, v.32, p.312-317, 1971. Available from: <https://academic.oup.com/jas/ article-abstract/32/2/312/4666565/>. Accessed: May, 21, 2019. doi: $10.2527 /$ jas $1971.322312 x$.

PANDORFI, H. et al. Conforto térmico para matrizes suínas em fase de gestação, alojadas em baias individuais e coletivas. Revista Brasileira de Engenharia Agrícola e Ambiental, v.12, p.326-332, 2008. Available from: <http://www.scielo.br/pdf/rbeaa/ v12n3/v12n03a15.pdf $>$. Accessed: May, 22, 2019. doi: 10.1590/ S1415-43662008000300015.

PERIN, J. et al. Evaporative snout cooling system on the performance of lactating sows and their litters in a subtropical region. Ciência Rural, v.46, p.342-347, 2016. Available from: $<\mathrm{http}: / /$ www.scielo.br/scielo.php?pid=S010384782015005041693\&script $=$ sci_arttext $>$. Accessed: May, 18, 2019. doi: $10.1590 / 0103-8478 \mathrm{cr} 20141693$.

POUND, P.; RITSKES-HOITINGA, M. Can prospective systematic reviews of animal studies improve clinical translation? Journal of Translational Medicine, v.18, p.1-6, 2020. Available from: $<$ https:// link.springer.com/article/10.1186/s12967-019-02205-x>. Accessed: May, 24, 2020. doi: 10.1186/s12967-019-02205-x.

QUINIOU, N.; NOBLET, J. Influence of high ambient temperatures on performance of multiparous lactating sows. Journal of Animal Science, v.77, p.2124-2134, 1999. Available from: <https:// academic.oup.com/jas/article-abstract/77/8/2124/4653366/>. Accessed: May, 21, 2019. doi: 10.2527/1999.7782124x.

RENAUDEAU, D.; NOBLET, J. Effects of exposure to high ambient temperature and dietary protein level on sow milk production and performance of piglets. Journal of Animal Science, v.79, p.1540-1548, 2001. Available from: <https:// academic.oup.com/jas/article/79/6/1540/4626000/>. Accessed: May, 20, 2019. doi: $10.2527 / 2001.7961540 x$.

RENAUDEAU, D. et al. Effect of ambient temperature on mammary gland metabolism in lactating sows. Journal of Animal Science, v.81, p.217-231, 2003. Available from: $<$ https://academic. oup.com/jas/article/81/1/217/4789846/>. Accessed: May, 22, 2019. doi: $10.2527 / 2003.811217 x$.

RIBEIRO, B. P. V. B. et al. Heat negatively affects lactating swine: A meta-analysis. Journal of Thermal Biology, v.74, p.325-330, 2018. Available from: <https://www.sciencedirect.com/science article/pii/S030645651830127X>. Accessed: May, 23, 2019. doi: 10.1016/j.jtherbio.2018.04.015

ROMANINI, C. E. B. et al. Physiological and productive responses of environmental control on housed sows. Scientia Agricola, v.65, p.335-339, 2008. Available from: <http://www.scielo. $\mathrm{br} / \mathrm{scielo} . \mathrm{php} ? \mathrm{pid}=\mathrm{S} 0103-90162008000400002 \&$ script $=\mathrm{sci}$ arttext>. Accessed: May, 16, 2019. doi: 10.1590/S010390162008000400002

ROSS, J. W. et al. Physiological consequences of heat stress in pigs. Animal Production Science, v.55, p.1381-1390, 2015. Available from: <https://pdfs.semanticscholar.org/ f1bf/6309305f499ec5df363f3aa346496174d6a2.pdf $>$. Accessed: May, 09, 2019. doi: 10.1071/AN15267.

ROSS, J. W. et al. 2017. Physiological mechanisms through which heat stress compromises reproduction in pigs. Molecular Reproduction and Development, v.84, p.934945, 2017. Available from: <https:/onlinelibrary.wiley.com/ doi/full/10.1002/mrd.22859>. Accessed: May, 09, 2019. doi: $10.1002 / \mathrm{mrd} .22859$.

SALLVIK, K.; WALBERG, K. The effects of air velocity and temperature on the behaviour and growth of pigs. Journal of Agricultural Engineering Research, v.30, p.305-312, 1984. Available from: <https://www.sciencedirect.com/science/article/ abs/pii/S0021863484800311>. Accessed: May, 20, 2019. doi: 10.1016/S0021-8634(84)80031-1

SAMPAIO, C. A. P. et al. Evaluation of the thermal environment in growing and finishing swine housing using thermal comfort indexes under tropical conditions. Ciência Rural, v.34, p.785-790, 2004. Available from: <http://www.scielo.br/scielo.php?pid=S010384782004000300020\&script $=$ sci arttext $>$. Accessed: Mar. 23, 2020. doi: $10.1590 / \mathrm{S} 0103-84782004000300020$.

SEELENBINDER, K. M. et al. Effects of heat stress during porcine reproductive and respiratory syndrome virus infection on metabolic responses in growing pigs. Journal of Animal Science, v.96, p.1375-1387, 2018. Available from: <https://academic.oup. com/jas/article-abstract/96/4/1375/4883207/>. Accessed: May, 09, 2019. doi: $10.1093 /$ jas/sky057.

SILVA, V. O. et al. Use of biodiesel co-products (Glycerol) as alternative sources of energy in animal nutrition: A systematic review. P Archivos de Medicina Veterinaria, v.46, p.111-120, 2014. Available from: <https://www.redalyc.org/ pdf/1730/173031253015.pdf >. Accessed: May, 07, 2019. doi: 10.4067/S0301-732X2014000100015.

STINN, J. P.; XIN, H. Heat and moisture production rates of a modern U.S. swine breeding-gestation-farrowing facility. ASHRAE Transactions, v.57, p.1517-1528, 2014. Available from: $<$ https://elibrary.asabe.org/abstract.asp?aid=45113 $>$. Accessed: May, 20, 2019. doi: 10.13031/trans.57.10711.

TURCO, S. H. N. et al. Environmental Thermal Evaluation of Different Conditioning Systems in Pigs Nursery. Revista Brasileira de Zootecnia, v.27, p.974-981, 1998. Available from: $<$ https://www.alice.cnptia.embrapa.br/bitstream/doc/133629/1/Re vistaBrasileiradeZootecniav.27n.5p.9749811998.pdf>. Accessed: May, 21, 2019.

WANG, K. et al. Assessment of hygrothermal conditions in a farrowing room with a wet-pad cooling system based on cfd simulation and field measurements. Transactions of the ASABE, v.57, p.1493-1500, 2014. Available from: <https://elibrary.asabe. org/abstract.asp?aid=45111>. Accessed: May, 20, 2019. doi: $10.13031 / \operatorname{trans} .57 .10634$

WEGNER, K. et al. Effects of temperature and temperature humidity index on the reproductive performance of sows during 
summer months under a temperate climate. Animal Science Journal, v.87, p.1334-1339, 2016. Available from: <https:// onlinelibrary.wiley.com/doi/abs/10.1111/asj.12569>. Accessed: May, 23, 2019. doi: 10.1111/asj.12569.

WILLIAMS, A. M. et al. Effects of a controlled heat stress during late gestation, lactation, and after weaning on the thermoregulation, metabolism, and reproduction of primiparous sows. Journal of Animal Science, v.91, p.2700-2714, 2013. Available from: $<\mathrm{https}: / /$ academic.oup.com/jas/article-abstract/91/6/2700/4717212/>. Accessed: May, 20, 2019. doi: 10.2527/jas.2012-6055.
WILDT, D. E. et al. Physiological temperature response and embryonic mortality in stressed swine. American Journal of Physiology, v.229, p.1471-1475, 1975. Available from: <https:// www.physiology.org/doi/abs/10.1152/ajplegacy.1975.229.6.1471>. Accessed: May, 22, 2019. doi: 10.1152/ajplegacy.1975.229.6.1471.

ZHANG, H. et al. Effect of dietary fat supplementation on milk components and blood parameters of early-lactating cows under heat stress. Slovak Journal of Animal Science, v.44, p.52-58, 2011. Available from: <https://sjas.ojs.sk/sjas/article/view/303>. Accessed: May, 21, 2019. 